\title{
BUTTERFLY PROBOSCES AND THEIR FUNCTIONAL RELATIONS WITH THE NECTAR PLANTS IN SOME SELECTED FORESTS
}

\author{
Sultana, S., S. Rahman, S. Akand, M. F. Hoque, M. S. Miah and M. A. Bashar \\ Environmental Biology and Biodiversity Laboratory (EBBL), Department of Zoology, University of \\ Dhaka, Dhaka-1000, Bangladesh
}

\begin{abstract}
An attempt was made to examine butterfly proboscis length and their significance in carrying out activities of the butterflies in relation to their nectar plants. Observations were made in seven selected areas (viz. Satchari, Modhupur, Rema-kalenga, Shaltila, Bhawal National Park, and Botanical and Zoological gardens of the Curzon hall area) from July 2014 to June 2015. Thirty four butterfly species of seven families, viz. Hesperiidae, Nymphalidae, Danaidae, Papilionidae, Pieridae, Lycaenidae and Satyridae, were observed. The strategic activities of proboscis in different butterflies were examined when they were used in foraging activity. The proboscis length of butterflies was measured during the study period. Nectar plants were identified in the laboratory. The corolla length of the nectar plants was measured in the field and found a good relation with the proboscis length of the butterflies. Among the observed species, hesperiid butterflies comparatively contain long proboscis, and can visit flowers up to $28 \mathrm{~mm}$ long corolla tube. The results obtained, indicate that the butterfly proboscis had significant role in co-evolution between the butterfly species and the flowers of the nectar plants.
\end{abstract}

Key words: Corolla, proboscis, nectar plant, foraging.

\section{INTRODUCTION}

Butterflies are often considered as opportunistic foragers (Sharp 1974). They can forage the vegetation of the soil surface layer, undergrowth layer and also the plants of the canopy layer (Bashar $e t$ al. 2015). They visit a wide range of flowers (Sharp 1974); and visit flowers to take nectar as their food mainly (Bashar 2015). The factors responsible for different flower preferences of butterflies include innate colour preferences (Ilse 1928, Boggs 1987), proboscis length (Cruden and Hermann-Parker 1979, Porter et al. 1992), corolla tube length of flowers, flower colors, floral scent and nectar quality, quantity and concentration (Ilse 1928, Erhardt 1991, Weiss 1995). Adult butterflies are divided into three categories (viz. nectar-feeding butterflies, fruit feeding butterflies and a combination of both) depending on food type (Gilbert 1972, DeVries 1988, DeVries et al. 1997, DeVries and Walla 2001, Molleman et al. 2005, Omura and Honda 2009). Most species of butterflies use flower nectar as primary food source (Bashar 2015). Butterflies accomplish pollination, a key stone ecological process in natural sustainability throughout the world (Kunte 2000). The foraging activity of butterflies benefits the plant species to achieve pollination and subsequent fruit set (Rani and Raju 2016). Butterflies are very important agents as diverse pollinators for plant species of canopy layer, man height layer and ground surface layer of vegetation in an ecosystem (Bashar 2015). They visit the flowers of their larval host plants and thereby contribute to the pollination of plants they eat at another life stage (Raju and Rao 2002). Due to development on vegetation, they both as adults and larvae, involve themselves in complex feeding relationships with green plants (Goodden 1974). Herbaceous plant species richness in a habitat plays a central role in its nectar plant species richness, and the nectar plant richness is a highly important factor supporting its adult butterfly species richness (Kitahara et al. 2008). The butterflies have to visit the plants because of their nutritional requirements in the adult stage, for egg laying supports of copulated females and host plant for larval food material (Bashar 2015). As such butterflies provide the best rapid indicators of habit quality (Godden 1974) and also, they are the best biotic sensitive indicators for assessing climatic changes (Bashar 2014). 
Proboscis in butterflies is very adaptive and vital organ in the adult (Bashar 2014). Butterflies possess long and coilable proboscis which enables the insects to take up liquid food (Krenn et al. 2002). Over $99 \%$ of lepidopteran species have a coilable proboscis, and these species represent the suborder Glossata (Krenn et al. 2005, Pogue 2009). Proboscis is a paired tube, comprising on of the components of the mouthparts and located on the head. The adult butterflies use the proboscis primarily to suck nectar from flowers, although various species feature specializations for additional food sources (Norris 1936). Proboscis is coilable, long and very flexible to feed on fluids by suction (Scoble 1992). In butterflies and moths, body size is a strong predictor of proboscis length (Corbet 2000, Agosta and Janzen 2005). Long proboscis observed in Hesperiidae is attributed to the coevolution with flowers having corolla tube (Kunte 2000). Maximum corolla depth of potential nectar plants limits species feeding on them to those with sufficiently long tongues; short-tongued butterfly species are therefore unable to feed on deep flowers and corolla depth has been shown to place a limit to exploitation by nectar feeding butterflies (Corbet 2000). The species with longest proboscis utilize the highest range of corolla tube depths. Thus, a long proboscis permits feeding on a greater variety of flower species (Ranta and Lundberg 1980). Foraging activities and proboscis uses are not the only functional keys for butterfly-sustenance, but they also enhance gene-flow mechanism in plant kingdom (Bashar et al. 2006). This creates good coevolutive ability both for plants and butterflies in different ecosystems (Bashar 2015). Moreover, this ability can maintain the healthiness of a forest ecosystem (Bashar 2014).

Given importance on the above statements, the present experiment was undertaken to examine the relationship between the proboscis-length of some butterflies of seven families, viz. Hesperiidae, Nymphalidae, Danaidae, Pieridae, Satyridae, Papilionidae and Lycaenidae; and corolla length of related plants. The aim of the study was to investigate morphic aspects of the experimental butterflies and of the related foraging flowers on one hand and on the other hand, the functional activities of the proboscis and textural adaptation of the flowers. The first one is morphic and the second one is dynamic part of the present investigation. The morphic part of the study represents the proboscis structure and their relationship with the nectar plants' flowers. The second part deals with the dynamic aspects of the butterfly probosces in pollination, i.e. the gene-flow mechanism in plant kingdom. But, to conduct any experiment on the second part, the first part stands more important for the study. Keeping the above hypothesis in front, present work was envisaged to carry out.

\section{MATERIAL AND METHODS}

The study was conducted from July 2014 to June 2015 at the forest of Satchari National Park (Habiganj), Modhupur National Park (Tangail), Rema-kalenga Wild Life Sanctuary (Habiganj), Shaltila (Sylhet), Bhawal National Park (Gazipur), Botanical Garden (Curzon Hall, Dhaka University) and Butterfly Germplasm center (Zoological garden, Curzon Hall, Dhaka University). Site selection was made according to the procedures of Marsh and Greer (1992) and Walpole and Sheldon (1999). Identification of butterflies was made following Bashar (2014) and Ek- Amnuay (2006) at the Environmental Biology and Biodiversity Laboratory (EBBL), Department of Zoology, University of Dhaka. Plant species were identified based on leaf characteristics including arrangement of leaves, leaf structure, leaf shape, leaf margin, leaf base, leaf tip, flower arrangements, fruit types and shapes following Ahmed et al. (2009).

The proboscis of butterflies under seven families examined following the method by Bashar (2014) with modification. The length of flower corolla tube and proboscis length of butterflies were measured in mm according to Kunte (2007) (Fig. 1). The proboscis length of live butterflies was measured after inserting a needle in to the center point of the coiled proboscis and straightening the proboscis out. The length was measured as the distance between the bases of labial palps to the tip of the proboscis. 


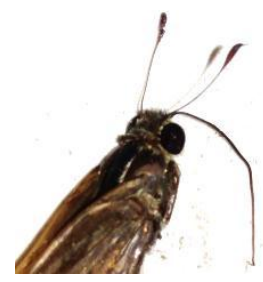

a

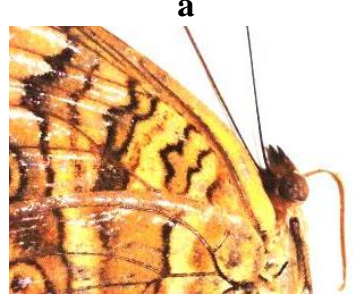

e
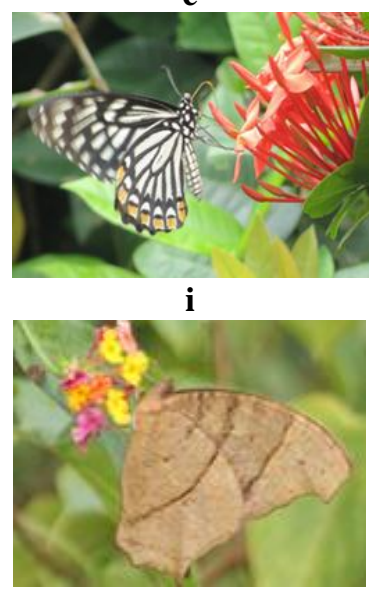

m

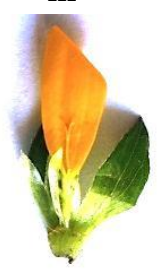

q

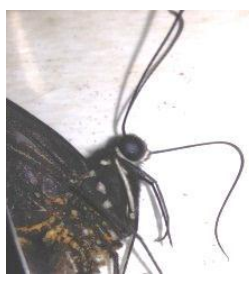

b

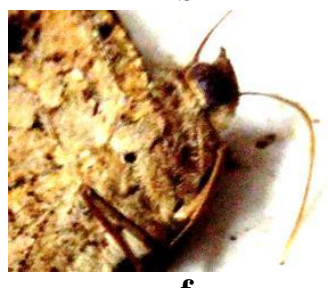

f

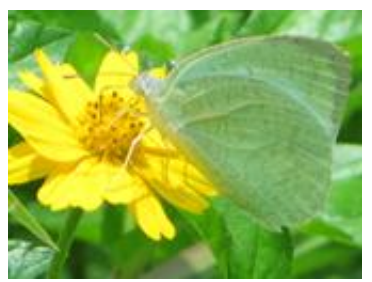

j

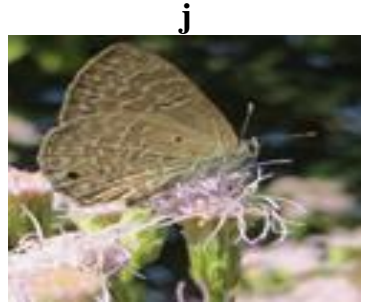

n

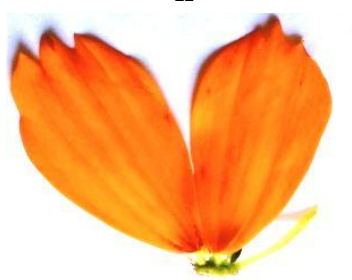

r

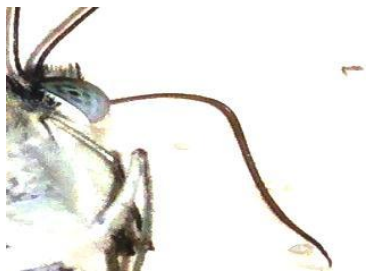

c

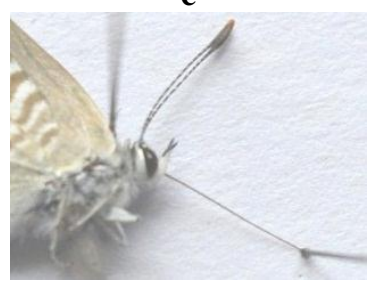

g

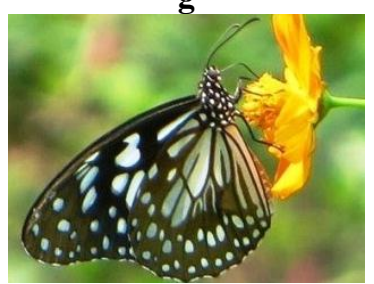

k

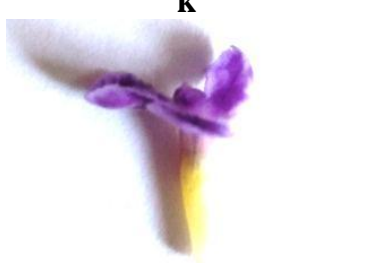

0

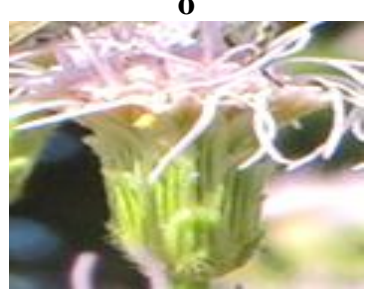

S

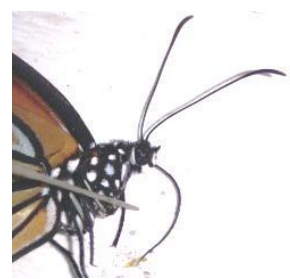

d

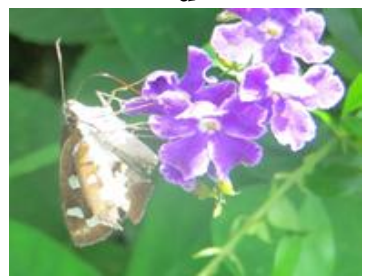

h

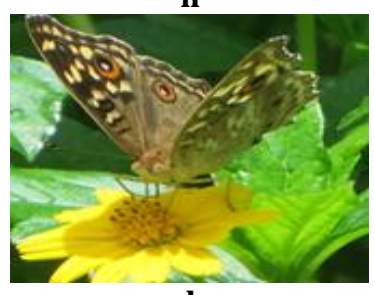

l

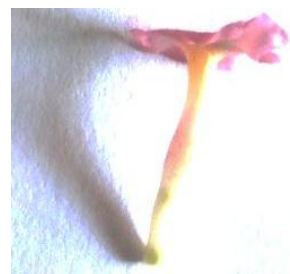

p

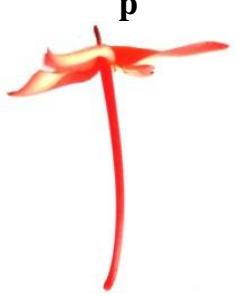

t

Fig. 1. Pictorial view of proboscis structure of butterflies, foraging activity of butterflies and corolla length of flowers; Proboscis structure (a-g) of examined butterfly: a. Parnara apostate (Hesperidae), b. Papilio polytes (Papilionidae), c. Catopsilia pomona (Pieridae), d. Danaus genutia (Danaidae), e. Junonia lemonias (Nymphalidae), f. Melanitis leda (Satyridae), g. Lampides boeticus (Lycaenidae); foraging activity on related plants (h-n): $\mathbf{h}$. Udaspes folus (Hesperidae) on Duranta plumieri, i. Chilasa clytia (Papilionidae) on Ixora coccinea, j. Leptosia nina (Pieridae) on Wedelia trilobata, k. Tirumala limniace (Danaidae) on Cosmos bipinnatus l. Junonia lemonias (Nymphalidae) on Wedelia trilobata, m. Melanitis leda (Satyridae) on Lantana camara, $\mathbf{n}$. Anthene emolus (Lycaenidae) on Eupatorium odoratum; flowers showing corolla length (o-t): o. Duranta plumieri (Corolla length $9 \mathrm{~mm}$ ), p. Lantana camara (Corolla length $10 \mathrm{~mm}$ ), q. Wedelia trilobata (Corolla length $2.5 \mathrm{~mm}$ ), r. Cosmos bipinnatus (Corolla length $17 \mathrm{~mm}$ ), s. Eupatorium odoratum (Corolla length $10 \mathrm{~mm}$ ), t. Ixora coccinea (Corolla length $27 \mathrm{~mm}$ ).

\section{RESULTS AND DISCUSSION}

The proboscis length of butterflies and the corolla length of nectar plants are presented in Table 1. A total of 34 species of butterflies was observed in the study area under seven families. And in most of the 
cases, they took the nectar of those flowers which bear nearly the same length of corolla tube in relation to their proboscis length. A single species of butterfly can visit different flowers during foraging (Bashar 2015). So, for every butterfly species 1 to 3 species of nectar plants were observed during the observation period. Proboscis is used by the adult strategically in relation to the flower structure in different butterfly families (Bashar 2015). The success of butterfly foraging depends, in part, on corolla length and clustering of flowers, and the proboscis length of butterflies.

Table 1. Proboscis length of the examined butterflies and the corolla length of flowers of related nectar plants.

\begin{tabular}{|c|c|c|c|c|c|c|}
\hline Family & Butterfly species & $\begin{array}{c}\text { Body length } \\
\text { (mm) }\end{array}$ & $\begin{array}{l}\text { Proboscis } \\
\text { length (mm) }\end{array}$ & $\begin{array}{c}\text { Observed nectar } \\
\text { plants }\end{array}$ & $\begin{array}{l}\text { Type of } \\
\text { plants }\end{array}$ & $\begin{array}{l}\text { Corolla } \\
\text { length }(\mathrm{mm})\end{array}$ \\
\hline \multirow{18}{*}{ 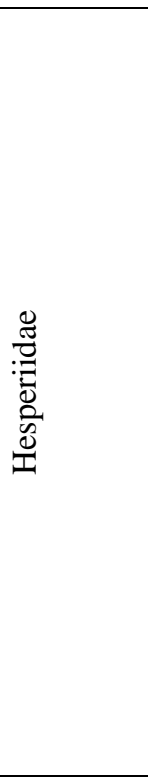 } & \multirow[t]{3}{*}{ Parnara apostate } & \multirow[t]{3}{*}{16} & \multirow[t]{3}{*}{14} & Wedelia trilobata & Herb & 2.5 \\
\hline & & & & Lantana camara & Shrub & 10 \\
\hline & & & & Duranta plumieri & Shrub & 9 \\
\hline & \multirow[t]{3}{*}{ Udaspes folus } & \multirow[t]{3}{*}{18} & \multirow[t]{3}{*}{24} & Duranta plumieri & Shrub & 9 \\
\hline & & & & Mussaenda frondosa & Shrub & 28 \\
\hline & & & & Catharanthus roseus & Shrub & 27.25 \\
\hline & \multirow[t]{3}{*}{ Pelopidas mathias } & \multirow[t]{3}{*}{15} & \multirow[t]{3}{*}{9} & Lantana camara & Shrub & 10 \\
\hline & & & & Pentas lanceolata & Herb & 13 \\
\hline & & & & Wedelia trilobata & Herb & 2.5 \\
\hline & \multirow[t]{3}{*}{ Suastus gremius } & \multirow[t]{3}{*}{15} & \multirow[t]{3}{*}{10} & Duranta plumieri & Shrub & 9 \\
\hline & & & & Lantana camara & Shrub & 10 \\
\hline & & & & Leucas zeylanica & Herb & 10 \\
\hline & \multirow[t]{3}{*}{ Hyarotis adrastus } & \multirow[t]{3}{*}{12} & \multirow[t]{3}{*}{10} & Pentas lanceolata & Herb & 13 \\
\hline & & & & Duranta plumieri & Shrub & 9 \\
\hline & & & & Eupatorium odoratum & Herb & 10 \\
\hline & \multirow[t]{3}{*}{ Pelopidas agna } & \multirow[t]{3}{*}{10} & \multirow[t]{3}{*}{7} & Wedelia trilobata & Herb & 2.5 \\
\hline & & & & Lantana camara & Shrub & 10 \\
\hline & & & & Catharanthus roseus & Shrub & 27.25 \\
\hline \multirow{15}{*}{ 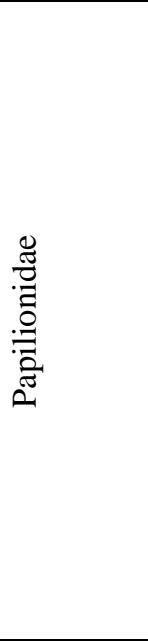 } & \multirow[t]{3}{*}{ Pachilopta aristolochiae } & \multirow[t]{3}{*}{31} & \multirow[t]{3}{*}{18} & Ixora coccinea & Shrub & 27 \\
\hline & & & & Lantana camara & Shrub & 10 \\
\hline & & & & Pentas lanceolata & Herb & 13 \\
\hline & \multirow[t]{3}{*}{ Papilio polytes } & 32 & 12 & Catharanthus roseus & Shrub & 27.25 \\
\hline & & & & Lantana camara & Shrub & 10 \\
\hline & & & & Eupatorium odoratum & Herb & 10 \\
\hline & Graphium doson & 27 & 22 & Ixora coccinea & Shrub & 27 \\
\hline & & & & Lantana camara & Shrub & 10 \\
\hline & & & & Zinia elegans & Shrub & 10 \\
\hline & Chilasa clytia & 25 & 14 & Zinia elegans & Shrub & 10 \\
\hline & & & & Lantana camara & Shrub & 10 \\
\hline & & & & Ixora coccinea & Shrub & 27 \\
\hline & Papilio demolius & 29 & 19 & Leucas zeylanica & Herb & 10 \\
\hline & & & & Zinia elegans & Shrub & 10 \\
\hline & & & & Ixora coccinea & Shrub & 27 \\
\hline & Junonia atlites & 23 & 13 & Tagetes erecta & Shrub & 10 \\
\hline & & & & Lantana camara & Shrub & 10 \\
\hline & & & & Pentas lanceolata & Herb & 13 \\
\hline : & Junonia lemonias & 22 & 10 & Wedelia trilobata & Herb & 2.5 \\
\hline$\frac{\pi}{2}$ & & & & Cosmos bipinnatus & Shrub & 17 \\
\hline$\Xi$ & & & & Eupatorium odoratum & Herb & 10 \\
\hline Z & Junonia almana & 22 & 11 & Lantana camara & Shrub & 10 \\
\hline & & & & Pentas lanceolata & Herb & 13 \\
\hline & & & & Eupatorium odoratum & Herb & 10 \\
\hline
\end{tabular}




\begin{tabular}{|c|c|c|c|c|c|c|}
\hline & \multirow[t]{3}{*}{ Phalantha phalantha } & \multirow[t]{3}{*}{20} & \multirow[t]{3}{*}{9} & Duranta repens & Shrub & 8 \\
\hline & & & & Lantana camara & Shrub & 10 \\
\hline & & & & Wedelia trilobata & Herb & 2.5 \\
\hline & \multirow[t]{3}{*}{ Pantoporia nefte } & \multirow[t]{3}{*}{20} & \multirow[t]{3}{*}{11} & Lantana camara & Shrub & 10 \\
\hline & & & & Duranta repens & Shrub & 8 \\
\hline & & & & Eupatorium odoratum & Herb & 10 \\
\hline \multirow{15}{*}{ 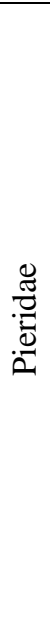 } & \multirow{3}{*}{ Eurema hecabe } & \multirow[t]{3}{*}{16} & \multirow[t]{3}{*}{9} & Spilanthes calva & Herb & 2.6 \\
\hline & & & & Lantana camara & Shrub & 10 \\
\hline & & & & Pentas lanceolata & Herb & 13 \\
\hline & \multirow[t]{3}{*}{ Eurema simulatrix } & \multirow[t]{3}{*}{17} & \multirow[t]{3}{*}{12} & Wedelia trilobata & Herb & 2.5 \\
\hline & & & & Eupatorium odoratum & Herb & 10 \\
\hline & & & & Tridax procumbens & Herb & 8 \\
\hline & \multirow[t]{3}{*}{ Letopsia nina } & \multirow[t]{3}{*}{12} & \multirow[t]{3}{*}{10} & Tridax procumbens & Herb & 8 \\
\hline & & & & Lantana camara & Shrub & 10 \\
\hline & & & & Eupatorium odoratum & Herb & 10 \\
\hline & \multirow[t]{3}{*}{ Catopsilia pomona } & \multirow[t]{3}{*}{17} & \multirow[t]{3}{*}{14} & Eupatorium odoratum & Herb & 10 \\
\hline & & & & Lantana camara & Shrub & 10 \\
\hline & & & & Zinia elegans & Shrub & 10 \\
\hline & Delias eucharis & 20 & 17 & Leucas zeylanica & Herb & 10 \\
\hline & & & & Duranta plumieri & Shrub & 9 \\
\hline & & & & Eupatorium odoratum & Herb & 10 \\
\hline & Tirumala limniace & 27 & 10 & Cosmos bipinnatus & Shrub & 17 \\
\hline & & & & Lantana camara & Shrub & 10 \\
\hline & & & & Heliotropium indicum & Herb & 3 \\
\hline & Euploea core & 35 & 13 & Wedelia trilobata & Herb & 2.5 \\
\hline & & & & Lantana camara & Shrub & 10 \\
\hline & & & & Pentas lanceolata & Herb & 13 \\
\hline$\frac{\pi}{0}$ & Danaus genutia & 24 & 8 & Cosmos bipinnatus & Shrub & 17 \\
\hline : & & & & Heliotropium indicum & Herb & 3 \\
\hline $\bar{\Xi}$ & & & & Eupatorium odoratum & Herb & 10 \\
\hline & Danaus chrysippus & 30 & 11 & Pentas lanceolata & Herb & 13 \\
\hline & & & & Lantana camara & Shrub & 10 \\
\hline & & & & Wedelia trilobata & Herb & 2.5 \\
\hline & Euploea mulciber & 28 & 9 & Duranta plumieri & Shrub & 9 \\
\hline & & & & Cosmos bipinnatus & Shrub & 17 \\
\hline & & & & Eupatorium odoratum & Herb & 10 \\
\hline & Anthene emolus & 12 & 7 & Eupatorium odoratum & Herb & 10 \\
\hline & & & & Tridax procumbens & Herb & 8 \\
\hline & & & & Cosmos sulphureus & Shrub & 14 \\
\hline & Rapala iarbus & 5 & 7 & Tridax procumbens & Herb & 8 \\
\hline & & & & Lantana camara & Shrub & 10 \\
\hline & & & & Eupatorium odoratum & Herb & 10 \\
\hline & Castalius rosimon & 9 & 8 & Heliotropium indicum & Herb & 3 \\
\hline$\frac{\pi}{\pi}$ & & & & Wedelia trilobata & Herb & 2.5 \\
\hline ల్లี & & & & Tridax procumbens & Herb & 8 \\
\hline ঠు & Lampides boeticus & 9 & 7 & Wedelia trilobata & Herb & 2.5 \\
\hline & & & & Duranta repens & Shrub & 8 \\
\hline & & & & Tridax procumbens & Herb & 8 \\
\hline & Spindasis lohita & 10 & 8 & Tridax procumbens & Herb & 8 \\
\hline & & & & Eupatorium odoratum & Herb & 10 \\
\hline & & & & Lantana camara & Shrub & 10 \\
\hline
\end{tabular}




\begin{tabular}{|c|c|c|c|c|c|c|}
\hline \multirow{7}{*}{ 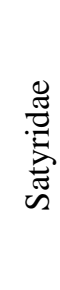 } & \multirow[t]{3}{*}{ Ypthima baldus } & \multirow[t]{3}{*}{22} & \multirow[t]{3}{*}{11} & Eupatorium odoratum & Herb & 10 \\
\hline & & & & Lantana camara & Shrub & 10 \\
\hline & & & & Tridax procumbens & Herb & 8 \\
\hline & \multirow[t]{3}{*}{ Melanitis leda } & \multirow[t]{3}{*}{20} & \multirow[t]{3}{*}{10} & Tridax procumbens & Herb & 8 \\
\hline & & & & Lantana camara & Shrub & 10 \\
\hline & & & & Mikania cordatum & Herb & 3.5 \\
\hline & Elymnias hypermnestra & 19 & 9 & Lantana camara & Shrub & 10 \\
\hline
\end{tabular}

Hesperiid butterflies always visited those flowers having corolla tube nearly similar to their proboscis length (Table 1). They were small bodied butterflies. The adult hesperiid butterflies utilized various plants as nectar source, most of which were shrubs and a few were herbs. They visited four types of herbs and four types of shrubs. The herbs were visited seven times, whereas, shrubs were visited eleven times by six species of hesperiids. The length of corolla tube ranged between $2.5 \mathrm{~mm}$ and $28 \mathrm{~mm}$. Among the six hesperiid species, Udaspes folus had $24 \mathrm{~mm}$ long proboscis using to take nectar from nine $\mathrm{mm}$ to $24 \mathrm{~mm}$ corolla tubes. Compared with the other five hesperiid species Pelopidas agna had very small proboscis having seven mm length. They visited flowers on the plants Wedelia trilobata, Lantana camara and Catharanthus roseus with $2.5 \mathrm{~mm}, 10 \mathrm{~mm}$ and $27.25 \mathrm{~mm}$ long corolla tubes, respectively. Suastus gremius and Hyarotis adrastus visited flowers having almost similar or smaller corolla tube compared with their proboscis length. However, proboscis length of Parnara apostate is greater than corolla length of the three visited nectar plants.

The proboscis of five examined nymphalid species varied between nine and thirteen $\mathrm{mm}$. The length of proboscis was generally half than their body length. The nymphalids preferred to visit both shrubs and herbs. They visited four types of shrubs and three types of herbs. Among the observed species, the maximum proboscis length was found in Junonia atlites $(13 \mathrm{~mm})$ and minimum in Phalantha phalantha (9 $\mathrm{mm})$. Except Junonia lemonias, all the species visited those flowers that have almost similar or smaller (2.5 to $13 \mathrm{~mm}$ ) corolla tube compared to their proboscis length. Junonia lemonias was often found on Cosmos bipinnatus which had $17 \mathrm{~mm}$ long corolla tube.

Danaid butterflies are large bodied butterflies. But the proboscis length is small and three times lesser than their body size. They chose the flowers with different length of corolla tube compare their proboscis length. For instance, Tirumala limniace possessed ten $\mathrm{mm}$ long proboscis and visited Cosmos bipinnatus, Lantana camara and Heliotropium indicum having the corolla length $17 \mathrm{~mm}, 10 \mathrm{~mm}$ and 3 $\mathrm{mm}$, respectively. Among the observed species, the maximum proboscis length was found in Euploea core $(13 \mathrm{~mm})$ and minimum in Danaus genutia $(8 \mathrm{~mm})$. Euploea core and Danaus chrysippus chose flowers with similar or shorter corolla length, but other species visited flowers with long corolla tube ranged between 2.5 and $17 \mathrm{~mm}$.

Papilionids are most beautiful butterflies among all butterflies. They bear longer proboscis than the length of corolla of their nectar plants. Like hesperiid butterflies, papilionids prefer to visit shrubs rather than herbs. Experimental papilionid species visited three types of herbs and four types of shrubs. Among the observed papilionids, Graphium doson has long proboscis $(22 \mathrm{~mm})$. It visited most of the flowers having smaller corolla length than its proboscis length. Compared with the other examined papilionid species, Papilio polytes possessed small proboscis which was $12 \mathrm{~mm}$ long. This butterfly visited flowers with corolla length ranging from 10-27.25 mm.

Pierids are conspicuous and brightly coloured butterflies. They preferred to visit herbs more than shrubs. The pierid species visited six types of herbs and three types of shrubs. They always visited flowers having corolla tube nearly similar to their proboscis length.

Among the pierid species, comparatively long proboscis $(17 \mathrm{~mm})$ was found in Delias eucharis. It collected nectar from flowers with corolla length 9-10 mm. Eurema hecabe possessed comparatively 
short proboscis $(9 \mathrm{~mm})$. Rest of the species visited flowers with almost similar or smaller corolla tube length (2.5-10 $\mathrm{mm})$ related to their proboscis length.

Lycaenids are small sized butterflies with small proboscis. Like pierid butterflies, they preferred to visit herbs rather than shrubs as nectar source. They chose flowers having similar and nearly similar corolla tube length compare to their proboscis length. Anthene emolus visited flowers with long corolla tube $(14 \mathrm{~mm})$, and the length was about double than its proboscis length. Proboscis length of other observed lycaenid species was 7-8 $\mathrm{mm}$. The corolla tube of their nectar flowers is usually found between 2.5 and $10 \mathrm{~mm}$ long.

Only three satyrid species were observed during the study period. They are small to medium sized butterflies. They visited flowers with nearly similar or smaller corolla length than their proboscis length. Elymnias hypermnestra visited only one nectar plant, Lantana camara with $9 \mathrm{~mm}$ corolla tube. It was almost equal to the proboscis length $(10 \mathrm{~mm})$ of $E$. hypermnestra.

Generally, butterflies with short proboscis did not visit the flowers with long corolla. Proboscis length varied among species. This could determine which flowers they would use for nectar collection. The butterflies with short proboscis only access nectar from short corolla tube, and with long proboscis can take nectar from flower which had deep corolla length and can gain higher energy from nectar plant (May 1992). During foraging, they also provide higher energetical reward to the nectar plants (May 1988).

It was found that, hesperiid and papilionid butterflies visited on shrubs while pierids, lycaenids and satyrids were exploring on herbs. This study reveals that, butterflies comprise shorter or even two to three times smaller proboscis than their body length except hesperiids. They visited flowers with similar or short corolla in relation to their proboscis length. The proboscis length of Papilio demolius was 19 $\mathrm{mm}$. it shows exceptional behaviour when it visits Ixora coccinea (corolla length $27 \mathrm{~mm}$ ). By contrast, hesperiids comprise proboscis nearly similar or even longer than their body size. The body length of Udaspes folus was $18 \mathrm{~mm}$ whereas its proboscis length was $24 \mathrm{~mm}$. It visits flowers with long corolla tube. This type of corolla tube was tough and in most cases unfruitful to other families. It was found that a great number of butterflies visited flowers in short corolla tube (2.5 to $10 \mathrm{~mm}$ ), while a very less number visited flowers with long corolla tube (17 to $28 \mathrm{~mm}$ ).

Selecting some plants is the characterization of foraging behaviour of the butterflies. The nectar collection happens to be a special strategy for them. This strategy depends on - the proboscis structure. When this strategy does adjust with the floral texture; the coevolution may exist between the butterfly and the selected plants flowers they visit; and butterfly prefers some selective plants to forage for nectar collection. They do not visit all the flowering plants and flowers to collect nectar. They may visit all flowers but may not forage for collecting nectar. Only the flowers are foraged when they remain within the range of its (butterflies) proboscis reaching capabilities or adaptabilities to collect nectar.

\section{REFERENCES}

Agosta, S. J. and D. H. Janzen. 2005. Body size distributions of large Costa Rican dry forest moths and the underlying relationship between plant and pollinator morphology. Oikos. 108: 183-193.

Ahmed, J. U., M. A. Hassan, Z. N. T. Begum and M. Khondker, 2009. Encyclopedia of Flora and Fauna of Bangladesh. Vol. 6-12. Asiatic Society of Bangladesh, Nimtali, Dhaka.

Bashar, M. A. 2014. Butterflies of Bangladesh: A broad approach for nature lovers. Vol. 1. 1st ed. BCTF Publications, Dhaka-1000. 515 pp.

Bashar, M. A. 2015. Butterflies of Bangladesh: A broad approach for nature lovers (EBBL Red-List and butterfly activities). Vol. 2. 1st ed. BCTF Publications. 177 pp. 
Bashar, M. A., H. R. Khan, S. Rahman, Eftesum, K. Chowdhury, M. M. Alam and G. Moula. 2015. Wildlife conservation through butterfly colonization. J. biodivers. conserv. bioresour. manag. 1(1): 71-82.

Bashar, M. A., M. A. Mamun, A. F. M. Aslam and A. K. Chowdhury. 2006. Biodiversity maintenance and conservation of Butterfly-Plant association in some forests of Bangladesh. Bangladesh J. Zool. 34(1): 55-67.

Boggs, C. L. 1987. Ecology of nectar and pollen feeding in Lepidoptera. Nutritional Ecology of Insects, Mites, Spiders and Related Invertebrates. Wiley, New York., pp. 369-391.

Corbet, S. A. 2000. Butterfly nectaring flowers: butterfly morphology and flower form. Entomol. Exp. Appl. 96: 289-298.

Cruden, R. W. and S. M. Hermann-parker. 1979. Butterfly pollination of Caesalpinia pulcherrima with observations on a psychophilous syndrome. J. Ecol. 67: 155-168.

DeVries, P. J. 1988. Stratification of fruit-feeding nymphalid butterflies in a Costa Rican rainforest. $J$. Res. Lepid. 26(1-4): 98-108.

DeVries, P. J. and T. R. Walla. 2001. Species diversity and community structure in neotropical fruitfeeding butterflies. Biol. J. Linn. Soc. 74(1): 1-15.

DeVries, P. J., D. Murray and R. Lande. 1997. Species diversity in vertical, horizontal, and temporal dimensions of a fruit-feeding butterfly community in an Ecuadorian rainforest. Biol. J. Linn. Soc. 62(3): 343-364.

Ek-Amnuay, P. 2006. Butterflies of Thailand: Fascinating Insects. American printing and publishing public, Bangkok. 2: 523-718.

Erhardt, A. 1991. Flower preferences, nectar preferences and pollination effects of Lepidoptera. Adv. Ecol. 1: 239-260.

Gilbert, L. E. 1972. Pollen feeding and reproductive biology of Heliconius butterflies. Proc. Natl. Acad. Sci. USA. 69(6): 1403-1407.

Goodden, R. 1974. Butterflies and Moths. Trans-world Publications Ltd., London. 70 pp.

Ilse, D. 1928. Uber den Farbsinn der Tagfalter. Zeit. Verg. Phys. 8: 658-692.

Kitahara, M., M. Yumoto and T. Kobayashi. 2008. Relationship of butterfly diversity with nectar plant species richness in and around the Aokighara primary woodland of Mount Fuji, central Japan. Biodivers. Conserv. 17: 2713-2734.

Krenn, H. W. and N. Muhlberger. 2002. Groundplan anatomy of the proboscis of butterflies (Papilionidae, Lepidoptera). Zool. Anz. 241: 396-380.

Krenn, H. W., J. D. Plant and N. U. Szucsich. 2005. Mouthparts of flower-visiting insects. Arthropod Struc. Develop. 34: 1-40.

Kunte, K. J. 2000. Butterflies of peninsular India. Indian Academy of Sciences, Bangalore and University Press, Hyderabad, India. 254 pp.

Kunte, K. J. 2007. Allometry and functional constraints on proboscis lengths in butterflies. Brit. Ecol. Soc., Func. Ecol. 21: 982-987. 
Marsh, C. W. and A. G. Greer. 1992. Forest land-use in Sabah, Malaysia: an introduction to Danum Valley. Trans. Ent. Soc. London. 333: 331-339.

May, P. G. 1988. Determinants of foraging profitability in two nectarivorous butterflies. Ecol. Entomol. 13: 171-184.

May, P. G. 1992. Flower selection and the dynamics of lipid reserves in two nectarivorous butterflies. Ecology. 73: 2181-2191.

Molleman, F., M. E. Alphen, P. M. Brakefield and B. J. Zwaan. 2005. Preferences and food quality of fruit-feeding butterflies in Kibale Forest, Uganda. Biotropica. 37(4): 657-663.

Norris, M. J. 1936. The feeding-habits of the adult Lepidoptera Heteroneura. Trans. Ent. Soc. London. 85: 61-90.

Omura, H. and K. Honda. 2009. Behavioral and electroantennographic responsiveness of adult butterflies of six nymphalid species to food-derived volatiles. Chemoecology. 19(4): 227-234.

Pogue, M. G. 2009. Biodiversity of Lepidoptera. In: R. G. Foottit and P. H. Adler (eds.). Insect Biodiversity: Science and Society. Wiley-Blackwell., pp. 325-355.

Porter, K., C. A. Steel and J. A. Thomas. 1992. The ecology of butterflies in Britain: Butterflies and communities. Oxford Univ. Press, New York., pp. 139-177.

Raju, A. J. S. and S. P. Rao. 2002. A case study on the decline of butterfly colonies in degraded habitats of Visakhapatnam. Andhra Univ. Res. Forum. 7: 57-59.

Rani, B. U. and A. J. S. Raju. 2016. A study on butterfly-flower interactions. J. Palyn. 52: 111-131.

Ranta, E. and H. Lundberg. 1980. Resource partitioning in bumblebees: the significance of differences in proboscis length. Oikos. 35: 298-302.

Scoble, M. J. 1992. The Lepidoptera: Form, Function and Diversity. Oxford University Press, New York., pp. 253-404.

Sharp, M. A., D. R. Parks and P. R. Ehrlich. 1974. Plant resources and habitat selection. Ecology. 55: 870-875.

Walpole, M. J. and I. R. Sheldon. 1999. Sampling butterflies in tropical rainforest: an evaluation of a transect walk method. Biol. Conserv. 87: 85-91.

Weiss, M. 1995. Associative color learning in nymphalid butterfly. Ecol. Entomol. 20: 298-301. 
J. biodivers. conserv. bioresour. manag. 3(1), 2017 